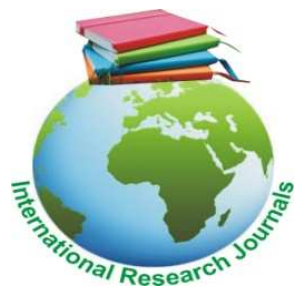

Journal of Medicine and Medical Sciences Vol. 9(1) pp. 001-008, January 2018

DOI: http:/dx.doi.org/10.14303/jmms.2018.011

Available online http://www.interesjournals.org/JMMS

Copyright (C) 2018 International Research Journals

Full Length Research Paper

\title{
A study of biomarker of inflammation in anaemic pregnant women
}

\author{
${ }^{1 / 2}$ Opeyemi O Adesina and *Mathias A Emokpae ${ }^{2}$ \\ ${ }^{1}$ Department of Medical Laboratory Science, Babcock University, Ilisan, Ogun State \\ ${ }^{2}$ Department of Medical Laboratory Science, School of Basic Medical Sciences University of Benin, Benin City, Nigeria \\ ${ }^{*}$ Corresponding Author's Email: mathias.emokpae@uniben.edu
}

\begin{abstract}
Low-grade inflammation has been reported in pregnancy. Previous studies suggested that C-reactive protein (CRP) levels are unaffected by anaemia, but levels may be altered in late pregnancy. It is not completely clear whether such alterations are dependent on anaemia status. We measured serum high sensitive C-reactive (hs-CRP) levels in pregnant women to know whether inflammation is higher in pregnant women with anaemia than non-anaemic pregnant women. A total of 1200 (400 from each centre) confirmed pregnant women attending antenatal clinics of Olabisi Onabanjo Teaching Hospital, Sagamu, General Hospital ljebu-Ode and General Hospital, Abeokuta were randomly enrolled in the study. The study participants were grouped based on haemoglobin concentrations as mild, moderate and severe anaemia. Packed cell volume, haemoglobin and hs-CRP were assayed using auto-analyzers and reagents supplied by Abbot Diagnostics BV (Wiesbaden, Germany and Hoofddorp, Netherlands respectively). The means hsCRP $(p<0.001)$ and $B M I(p=0.017)$ in anaemic pregnant women were higher than non-anaemic pregnant women. The means hs-CRP for mild, moderate and severe anaemic conditions were $4.9 \pm 0.19 \mathrm{mg} / \mathrm{L}, 5.0 \pm 0.16 \mathrm{mg} / \mathrm{L}$ and $9.4 \pm 1.81 \mathrm{mg} \mathrm{Ll}$. The Duncan multiple test shows that the hs-CRP value in severe was significantly higher $(p<0.05)$ than mild and moderate while the means of mild and moderate anaemic conditions were not significantly different from each other. In conclusion, hs-CRP levels were significantly higher in anaemic pregnant women than non-anaemic pregnant women, the elevation of hs-CRP levels were associated with severity of anaemia. Adequate ante-natal management of pregnant women cannot be overemphasized to avoid the complications associated with anaemia and inflammation.
\end{abstract}

Keywords: Anaemia, body mass index, high-sensitive C-reactive protein, pregnancy.

\section{INTRODUCTION}

Anaemia in pregnancy is a global public health challenge and is associated with maternal morbidity and mortality (Allen, 2000). It is the most common heamatological problem in pregnant women (Choi et al., 2005). Anaemia in pregnancy is more common in developing than in developed countries. In the United States of American (USA), less than $30 \%$ of pregnant women develop anaemia whereas the prevalence rate in Africa, Asia, and Latin America ranges from $35 \%$ to $75 \%$ (Brabin et al., 2001; Vanden Broek et al., 1998). About 56\% of pregnant women in developing countries are anaemic with half of the cases attributed to iron deficiency (Allen,
2000). Recent report in Northern Nigeria suggests that about $60 \%$ of pregnant women are anemic (Nwizu et al., 2011). Anaemia is regarded as a major risk factor for an unfavorable pregnancy outcome. It has been associated with premature labour and low birth weight (Brabin et al., 1990; Scholl et al., 2011), and perinatal mortality (Abourzahr and Royston, 1991; Murphy et al., 1986). During pregnancy, anaemia increases 4-fold from the 1st to the 3rd trimester in the low-income women monitored as part of pregnancy nutritional surveillance by the Centre for disease control (CDC) (Zimmerman et al., 2007). 
Elevated CRP levels during pregnancy, as a marker of low-grade inflammation, has been reported to be associated with increased risks of fetal growth restriction and neonatal complications, such as preterm birth, low birth weight, and small size for gestational age (SGA) (Poole et al., 2013; Genc et al., 2011; Tjoa et al., 2003). The hsCRP has also been described as biomarker inflammation or infection for assessing changes in nutritional status (WHO, 2014). The levels are known to slightly increase in pregnancy (Mandal et al., 2016; Redman and Sargent, 2009), but it is not completely clear whether such alterations are dependent on anaemia status. In addition to comparing the utilization of acute phase proteins in the interpretation of serum ferritin and retinol levels, the WHO supported the development of an International Standards for CRP $(85 / 506)$ by the National Institute for Biological Standards and Control for the use of calibrant for CRP assays (WHO, 2008). It is therefore essential to investigate the relationship between anaemia in pregnancy and acute phase proteins. Previous studies have reported that CRP levels are unaffected by anaemia, protein levels, red blood cell shape or patient age or sex. However, in women, CRP concentrations tend to be higher late in pregnancy (Young et al., 1991).

C-reactive protein (CRP) is one of the most sensitive acute-phase reactants. Plasma CRP levels can increase dramatically (100-fold or more) after severe trauma, bacterial infection, inflammation, surgery, or neoplastic proliferation (Haverkate et al., 1997).

C-reactive protein (CRP) is synthesized throughout the body, especially by immune cells, the liver, and by adipocytes (fat cells). Recent awareness of the utility of measuring CRP as a risk factor for cardiovascular disease has led to the development of high-sensitivity CRP (hs-CRP) assays to detect lower levels of CRP; these assays are sensitive to $0.5-10 \mathrm{mg} / \mathrm{L}$ (Mandal et al., 2016; Shetkar and Pyati, 2017). CRP is an incredibly sensitive and robust marker of general inflammation and It is used to track the progress of chronic inflammatory conditions such as rheumatoid arthritis, vasculitis, or inflammatory bowel diseases like Crohn's disease (Vermeire, 2004; Du Clos, 2003).

In those cases, increased symptoms accompanied by a rise in CRP signals a "flare" of the disease, and indicate the need to provide anti-inflammatory therapy. It rises quickly after an inflammatory attack, but should return to normal levels when the inflammation or tissue destruction is resolved. When CRP remains high, it is an indication of chronic inflammation. Elevated CRP signals increased risk for many chronic inflammation-related disorders, including cardiovascular disease, cancer, diabetes, obesity, and more. When CRP binds to phosphocholine expressed on the surface of damaged cells, polysaccharides and peptosaccharides present on bacteria, parasites and fungi, it activates the classical complement cascade of the immune system. This regulates the activity of phagocytic cells, supporting the role of CRP in the opsonization of infectious agents and dead or dying cells (WHO, 2014).

Low-grade inflammation is associated with endothelial dysfunction, leading to vascular dysfunction and suboptimal placental development. Maternal systemic inflammation might also be a response to ischemia of the placenta, due to suboptimal placentation (Lam et al., 2005 and Redman, 2004). Subsequently, suboptimal placental development might predispose mothers to increased risks for various pregnancy complications (Mandal et al., 2016; Redman and Sargent, 2009). We measured serum hs-CRP to better characterize anemia status in pregnant women. Our primary goal in this study was to ascertain whether inflammation is higher in pregnant women with anemia defined as haemoglobin levels $<110 \mathrm{~g} / \mathrm{L}$ than non-anaemic pregnant women.

\section{MATERIALS AND METHODS}

This is a multi- centre cohort study conducted at three urban centres in Ogun State, Nigeria. This is a hospitalbased study and was conducted between April, 2015 and July, 2016. Blood and urine samples were obtained from 1200 (400 from each health institution) confirmed pregnant women attending antenatal clinics of OlabisiOnabanjo Teaching Hospital, Sagamu (OOUTH), General Hospital ljebuode (GHI) and General Hospital Abeokuta (GHA). These hospitals provide tertiary and secondary medical care for the regional population of Ogun State and other neighboring communities. All pregnant women attending the antenatal clinics for the first time irrespective of the gestational age were enrolled into the study and non-anaemic pregnant women of same strata group were used as control. Structured questionnaire was administered to obtain demographic and clinical information of the participants.

\section{Inclusion and exclusion criteria}

Pregnant women with Systemic diseases or malignancies or those who do not give consent were excluded. All pregnant women on vitamin $\mathrm{C}$ were excluded from the study. The pregnant women included in the study were those diagnosed clinically and biochemically who gave informed consent, without other medical disorders or pregnancy related complications.

\section{Ethical consideration}

The study protocol was reviewed and approved by the ethics committees of Olabisi Onabanjo Teaching Hospital (NHREC/08/10/2012; dated 22nd September, 2015), General Hospital ljedu-Ode (PER/A/Vol1/130; dated 27th May 2015 and General Hospital Abeokuta (2265/03; 
dated 23rd April, 2015). The participants gave informed consent before they were enrolled in the study.

\section{Specimen collection}

The early morning urine and $5 \mathrm{~mL}$ of blood were collected from the pregnant women. Two millilitres of blood was dispensed in to EDTA container and was used for haemoglobin and packed cell volume using haematology auto-analyzer Coulter counter cell dye by Abott diagnostics (Wiesbaden, Germany)The concentration of potassium EDTA was $1.5-2.0 \mathrm{mg} / \mathrm{mL}$ of blood, while $3 \mathrm{~mL}$ was emptied into plain plastic tube and was allowed to cloth at $4^{\circ} \mathrm{C}$ for 30 mins. It was thereafter centrifuged at $300 \mathrm{rpm}$ for 10 minutes and serum separated into another plain container and was stored frozen at $-20^{\circ} \mathrm{C}$ until analysis was done. On the average, biochemical analysis was carried out every 3 weeks to allow for collection of a sample size good enough to run a pack of kit. The study participants were grouped based on haemoglobin concentrations. A balanced number of subjects from the strata $\mathrm{Hb} 70-89 \mathrm{~g} / \mathrm{l}, \mathrm{Hb} 90-109 \mathrm{~g} / \mathrm{l}, \mathrm{Hb}$ 110-149 $\mathrm{g} / \mathrm{l}$, and all with $\mathrm{Hb} 150 \mathrm{~g} / \mathrm{l}$ were included (Hinderaker et al., 2001). The early morning urine was used for pregnancy test.

Gestational age (in weeks) at enrolment was calculated from the reported first day of the last menstrual period. The expected gestational age at birth was calculated using an ultrasonography report by the attending physician.

Urine was examined at the laboratory using a reagent strip and the definitions of positive specimens were followed according to the instructions of the manufacturer. Anaemic cases were classified as mild, moderate or severe based on haemoglobin threshold used to define anaemia in pregnant women.

\section{Maternal anthropometry}

The anthropometric measurement was done by qualified nurses at the centres. A digital balance (Salter's 9016, Kent, UK) was used to record the weights of all mothers to the nearest $100 \mathrm{~g}$. Weight was measured without shoes, jackets or cardigans, heavy jewellery, loose chains or keys. They were asked to stand with their feet together at the centre and their heels against the back edge of the scale. They were asked to keep their arms hanging loosely and head facing forward. Measurements of height were made using a stadiometer to the nearest $0.1 \mathrm{~cm}$. They were asked to remove their shoes and stand with their feet flat on the centre of the base plate, back straight, feet's together, heels against the rod, eyes straight and Frankfurt plane in a horizontal position (WHO, 1995). Maternal body mass index (BMI) was calculated as weight in $\mathrm{kg}$ by the square of height in meters $(\mathrm{kg} / \mathrm{m} 2)$.

\section{Laboratory determination of serum hs-CRP}

SerumhsCRP was determined by immune turbidometrycolorimetry assay using reagents supplied by Abbot Diagnostics BV (Hoofddorp, Netherlands).

Principle: Turbidimetric Immunoassay is based on the principle of agglutination reaction for the ultrasensitive determination of $\mathrm{C}$ - reactive protein in human serum. The test specimen was mixed with latex reagent and activation buffer and was allowed to react. Presence of hsCRP in the test specimen results in the formation of an insoluble complex producing a turbidity, which was measured at wavelength of $550 \mathrm{~nm}$. The increase in turbidity corresponds to the concentration of CRP in the test specimen.

\section{Statistical analysis}

For All data entry Epilnfo 5.0 and 6.04b was used (Dean et al., 1994). All analyses of data were converted from Epilnfo $6.04 \mathrm{~b}$ to SPSS version 20.0 (Chicago, IL, USA). Descriptive analysis such as mean \pm standard deviations, 95\% confidence of intervals $(95 \% \mathrm{Cl}$ ), (minimums and maximums) of the laboratory variables in subgroups defined was used. Analysis of variance (ANOVA) was carried out to ascertain if there was a significant difference between the different classes of anaemic conditions. The associations between anaemia and its determinants were examined by multiple logistic regression analysis. A p-value $\leq 0.05$ was considered significant.

\section{RESULTS}

\section{Age distribution}

The age distribution is presented in table 1 . The overall dominant age groups in the population were 27-31 years $(34.8 \%)$, followed by age group $32-36$ years $(29 \%)$. The least represented age group was 40 years and above $(2.5 \%)$. This was the same for all the three study centers. However, there was no significant association between age groups and communities ( $p>0.05$ ).

Table 2 shows the number of pregnant women with haemoglobin levels $<11 \mathrm{~g} / \mathrm{dl}$ (anaemic) and $\geq 11 \mathrm{~g} / \mathrm{dl}$ nonanaemic.

The number of pregnant women with haemoglobin levels $<11 \mathrm{~g} / \mathrm{dl}$ (anaemic) and $\geq 11 \mathrm{~g} / \mathrm{dl}$ non-anaemic distribution is presented in table 2 . The overall nonanaemic and anaemic respondents were $634(52.8 \%)$ and (566) $47.2 \%$ respectively. This pattern was the same for Sagamu with non-anaemic respondent higher than 
004 J. Med. Med. Sci.

Table 1: Age distribution in overall and the different centers

\begin{tabular}{lccccccccc}
\hline Age(Years) & \multicolumn{2}{c}{ Overall } & \multicolumn{3}{c}{ Abeokuta } & \multicolumn{2}{c}{ ljebuode } & \multicolumn{2}{c}{ Sagamu } \\
\hline & Freq & $(\%)$ & Freq & $(\%)$ & Freq & $(\%)$ & Freq & $(\%)$ \\
\cline { 2 - 9 } 18-21 years & 48 & 4 & 24 & 6 & 18 & 4.5 & 6 & 1.5 \\
22-26 years & 262 & 21.8 & 96 & 24 & 100 & 25 & 66 & 16.5 \\
$27-31$ years & 418 & 34.8 & 130 & 32.5 & 140 & 35 & 148 & 37 \\
32-36 years & 348 & 29 & 112 & 28 & 98 & 24.5 & 138 & 34.5 \\
37-40 years & 90 & 7.5 & 24 & 6 & 36 & 9 & 30 & 7.5 \\
40 year and above & 30 & 2.5 & 10 & 2.5 & 8 & 2 & 12 & 3 \\
No Reponse & 4 & 0.3 & 4 & 1 & & & & \\
Total & $\mathbf{1 2 0 0}$ & $\mathbf{1 0 0}$ & $\mathbf{4 0 0}$ & $\mathbf{1 0 0}$ & $\mathbf{4 0 0}$ & $\mathbf{1 0 0}$ & $\mathbf{4 0 0}$ & $\mathbf{1 0 0}$ \\
\hline
\end{tabular}

$X^{2}=14.911, \mathrm{df}=10, \mathrm{p}=0.135$

Table 2: Number of pregnant women with haemoglobin levels $<11 \mathrm{~g} / \mathrm{dl}$ (anaemic) and $\geq 11 \mathrm{~g} / \mathrm{dl}$ non-anaemic

\begin{tabular}{lcccccccc}
\hline Hb $(\mathbf{g} / \mathbf{d l})$ & \multicolumn{2}{c}{ Overall } & \multicolumn{2}{c}{ Abeokuta } & \multicolumn{2}{c}{ ljebuode } & \multicolumn{2}{c}{ Sagamu } \\
\hline & Freq & $(\%)$ & Freq & $(\%)$ & Freq & $(\%)$ & Freq & $(\%)$ \\
\cline { 2 - 9 } Non-anaemic $(\mathrm{Hb} \geq 11 \mathrm{~g} / \mathrm{d})$ & 634 & 52.8 & 168 & 42 & 176 & 44 & 290 & 72.5 \\
Anaemic $(\mathrm{Hb}<11 \mathrm{~g} / \mathrm{dl})$ & 566 & 47.2 & 232 & 58 & 224 & 56 & 110 & 27.5 \\
Total & $\mathbf{1 2 0 0}$ & $\mathbf{1 0 0}$ & $\mathbf{4 0 0}$ & $\mathbf{1 0 0}$ & $\mathbf{4 0 0}$ & $\mathbf{1 0 0}$ & $\mathbf{4 0 0}$ & $\mathbf{1 0 0}$ \\
\hline
\end{tabular}

$X^{2} 46.723, \mathrm{df}=2, \mathrm{p}<0.001$

Table 3: The comparison of inflammation marker in anaemic and non-anaemic pregnant women

\begin{tabular}{lcccc}
\hline Parameters & Non- Anaemic $\mathbf{n}=\mathbf{6 3 4}$ & Anaemic $\mathbf{n}=\mathbf{5 6 6}$ & $\mathrm{p}$-value & Significance \\
\hline $\operatorname{hsCRP}(\mathrm{mg} / \mathrm{dl})$ & $4.3 \pm 0.22$ & $7.4 \pm 0.33$ & 0.001 & $\mathrm{p}<0.001$ \\
$\operatorname{BMl}\left(\mathrm{kg} / \mathrm{m}^{2}\right)$ & $22.0 \pm 0.34$ & $23.8 \pm 0.40$ & 0.017 & $\mathrm{p}<0.017$ \\
\hline
\end{tabular}

anaemic population (72.5\%) and (27.5) \% except in Abeokuta and ljebu-Ode where anaemic population was higher than non-anaemic population. However, there was a significant association between haemoglobin and communities $(p<0.05)$.

\section{Comparison of inflammation status in anaemic and non-anaemic pregnant women in the study centres}

The meanshsCRP $(p<0.001)$, and BMI $(p=0.017)$ of anaemic pregnant women were higher than the in nonanaemic pregnant women. The unpaired t-test shows that there was a statistical significant difference $(p<0.05)$ between the hsCRP, BMl levels in non-anaemic and anaemic pregnant women.
The Relationship between hsCRP levels and severity of anaemia in pregnant women

The mean $\mathrm{Hb}$ and PCV of the study population for nonanaemic pregnant women was higher $(p<0.05)$ than the mean $\mathrm{Hb}$ and $\mathrm{PCV}$ in anaemic pregnant women. The unpaired t-test shows that there was highly significant difference $(p<0.001)$ between the level in non-anaemic and anaemic pregnant women.

The mean of hsCRP for mild, moderate and severe anaemic condition were $4.9 \pm 0.19 \mathrm{mg} / \mathrm{l}, 5.0 \pm 0.16 \mathrm{mg} / \mathrm{l}$ and $9.4 \pm 1.81 \mathrm{mg} / \mathrm{l}$. The analysis of variance shows that there was significant difference between mild, moderate and severe anaemic conditions. The Duncan multiple test shows that the hsCRP value in severe was significantly higher $(p<0.05)$ than mild and moderate while the means 
Table 4: Comparison of hsCRP according to severity of anaemia in pregnant women

\begin{tabular}{lccccc}
\hline Measured variables & Mild & Moderate & Severe & $\mathrm{p}$-value & Significance \\
\hline $\mathrm{Hb}(\mathrm{g} / \mathrm{dl})$ & $10.4 \pm 0.03^{\mathrm{a}}$ & $8.93 \pm 0.05^{\mathrm{b}}$ & $6.68 \pm 0.239^{\mathrm{b}}$ & 0.000 & $\mathrm{p}<0.001$ \\
& $(10-11)$ & $(7-11)$ & $(6-7)$ & & \\
$\mathrm{PCV}(\%)$ & $32.2 \pm 0.19^{\mathrm{a}}$ & $29.9 \pm 0.22^{\mathrm{a}}$ & $22.8 \pm 1.44^{\mathrm{b}}$ & 0.000 & $\mathrm{p}<0.001$ \\
& $(28-40)$ & $(19-40)$ & $(19-25)$ & & \\
$\mathrm{HsCRP}(\mathrm{mg} / \mathrm{L})$ & $4.9 \pm 0.19^{\mathrm{b}}$ & $5.0 \pm 0.16^{\mathrm{b}}$ & $9.4 \pm 1.8^{\mathrm{a}}$ & 0.002 & $\mathrm{p}<0.002$ \\
& $(0-12)$ & $(0-12)$ & $(6-13)$ & & \\
\hline
\end{tabular}

Values in parenthesis are minimum-maximum levels

Table 5: Comparison of measured parameter among pregnant women during first, second and third trimester of pregnancy

\begin{tabular}{lcccc}
\hline Inflammatory status & First trimester & Second trimester & Third trimester & $\mathrm{p}$-value \\
\hline $\mathrm{hsCRP}(\mathrm{mg} / \mathrm{L})$ & $3.7 \pm 0.26^{\mathrm{C}}$ & $4.6 \pm 0.13^{\mathrm{b}}$ & $6.7 \pm 0.18^{\mathrm{a}}$ & 0.000 \\
& $(0-12)$ & $(0-12)$ & $(1-19)$ & \\
$\mathrm{BMl}\left(\mathrm{kg} / \mathrm{m}^{2}\right)$ & $19.0 \pm 0.24^{\mathrm{b}}$ & $21.3 \pm 0.23^{\mathrm{b}}$ & $23.0 \pm 0.42^{\mathrm{b}}$ & 0.780 \\
& $(18.0-28.00)$ & $(16.9-34.2)$ & $(17.9-34.4)$ & \\
\hline
\end{tabular}

Note: $p>0.05=$ No significant association, $p<0.05=$ significant association, $p<0.01, p<0.02$ $=$ high significant association, $\mathrm{p}<0.001=$ very high significant association; Similar letters indicate means that are not significantly different.

of mild and moderate anaemic conditions were not significantly different $(p>0.05)$ from each other (table 4$)$.

\section{High Sensitive C-reactive Protein (hsCRP)}

The mean hsCRP during the first trimester was $3.7 \pm 0.26 \mathrm{mg} / \mathrm{L}$, second trimester $4.62 \pm 0.125 \mathrm{mg} / \mathrm{l}$ and third $6.9 \pm 0.18 \mathrm{mg} / \mathrm{l}$ respectively. The analysis of variance shows that there is significant difference between gestational periods. Although, Duncan multiple test shows that the hsCRP in $3^{\text {rd }}$ trimester was significantly higher than $1^{\text {st }}$ and 2 nd trimester $p<0.000$. The analysis of variance shows that there was highly significant difference $(p<0.05)$ in the concentration of hsCRP.

\section{Body mass index $\left(\mathrm{Kg} / \mathrm{m}^{2}\right)$}

The mean BMI $\left(\mathrm{Kg} / \mathrm{m}^{2}\right)$ during the first trimester was 19.0 $\pm 0.24 \mathrm{~kg} / \mathrm{m}^{2}$, second trimester $21.3 \pm 0.23 \mathrm{~kg} / \mathrm{m}^{2}$ and third trimester $23.0 \pm 0.42 \mathrm{~kg} / \mathrm{m}^{2}$ respectively. The analysis of variance shows that there was no significant difference $(p>0.05)$ in various trimester and BMI.

\section{DISCUSSION}

Low grade inflammation has been reported in uncomplicated pregnancy (Young et al., 1991) but previous studies have reported that CRP levels are unaffected by anaemia, protein levels, red blood cell shape or patient age or sex. The data from this study indicate that hs-CRP was significantly higher $(p<0.001)$ in anaemic pregnant women than non-anaemic counterparts. The levels of hs-CRP increased with severity of anaemia $(p<0.05)$ with levels significantly higher $(p<0.05)$ in severe than mild and moderate anaemia. The hs-CRP also increased with duration of pregnancy and Duncan multiple test shows that the hsCRP in 3rd trimester was significantly higher $(p<0.001)$ than 1 st and 2nd trimesters.

Levels of severity of anaemia in developing countries were taken as: $10.0-10.9 \mathrm{~g} / \mathrm{d} 1$ (mild anaemia);7-9.9g/dl (moderate anaemia) and $<7 \mathrm{~g} / \mathrm{dl}$ (severe anaemia) (WHO, 1989). Acceptable haemoglobin ( $\mathrm{Hb})$ during pregnancy is taken to be $\geq 11 \mathrm{~g} / \mathrm{dl}$ (WHO, 1993) in developing countries. Values higher than these are said to be non-anaemic. Equally haemoglobin level of less than $11 \mathrm{~g} / \mathrm{dL}$ during the first and third trimesters and less than $10.5 \mathrm{~g} / \mathrm{dL}$ during the second trimester (CDC, 1989) was regarded as anaemic pregnancy.

The assay of serum high sensitivity CRP (hs-CRP) is now used to measure inflammation, especially in cardiovascular disease. It is better at discriminating even very small increases in CRP measurements at the lowest levels. While Life Extension currently recommends an optimal hs-CRP of less than $1.0 \mathrm{mg} / \mathrm{L}$ for women and less than $0.55 \mathrm{mg} / \mathrm{L}$ for men, standard laboratory testing uses the following risk stratification for hs-CRP (Worwood, 
006 J. Med. Med. Sci.

2007): Lowest risk range is less than $1.0 \mathrm{mg} / \mathrm{L}$; Average risk is 1.0 to $3.0 \mathrm{mg} / \mathrm{L}$ while highest risk category is greater than $3.0 \mathrm{mg} / \mathrm{L}$.

Serum CRP should not be confused with high sensitivity CRP (hs-CRP). The hs-CRP assay has been modified from the usual serum CRP assay to increase its sensitivity and detect very minor elevations in serum CRP. Excess of serum ferritin is dangerous as high level of stored iron is also toxic (Shetkar and Pyati, 2017). Plasma ferritin measured either when pregnancy is being planned or in early first trimester is a reliable biomarker of body iron reserves and can be used to tailor an individual iron prophylaxis regimen). Serum ferritin is an acutephase protein that increases during inflammation and infection. Measurements of CRP and a1-acid glycoprotein (AGP) are suggested as a useful way to identify subjects with high ferritin due to infection or inflammation. Although its measurement is currently expensive, transferring receptor, which is little influenced by infection, can be used to better define iron deficiency anaemia and a combination of transferrin receptor and serum ferritin can be used to calculate body iron stores (Cook, 2003).

In the evaluation of patients with suspected iron depletion states, an elevated CRP helps with interpreting ferritin results; a normal ferritin is unreliable as an indicator of adequate iron stores in patients with an elevated CRP, since ferritin itself is an acute phase reactant. An elevated hs-CRP may indicate an increase in serum hepcidin and functional iron deficiency in the presence of adequate serum iron or reticuloendothelial iron (WHO, 2014).

The mean hsCRP observed in anaemic pregnant women was higher $(p<0.001)$ than non- anaemic pregnant women. This observation is consistent with previous study which associated increased levels of hsCRP with anaemia. In normal pregnancy, free radicals are still generated. These free radicals are beneficial to the body at physiological levels, but when their production rates overwhelm the synergistic actions of available antioxidants, several deleterious or harmful conditions may ensue, including adverse pregnancy outcomes.

The total number of non-anaemic respondents with normal hsCRP was higher $(\mathrm{p}<0.05)$ than anaemic group. This could likely be due to higher oxidation activities that occur during pregnancy resulting in massive mobilization of antioxidant defences, and subsequent reduction in the levels of antioxidants. However abnormal hsCRP recorded in this study was higher $(p<0.05)$ than that reported among pregnant women in Ethiopia and Enugu (Ogbodo et al., 2014; Ogbodo et al., 2013;Knapen et al., 1999). Pregnancy is an inflammatory stressor and CRP serves as an early marker of inflammation or infection (Scholl et al., 2011; Pitiphat et al., 2007) in their study recorded very high levels of maternal plasma CRP in early pregnancy which was associated with increased risk of preterm delivery. The CRP concentration in peripheral circulation is also known to be associated with Body Mass Index (BMI) and other marker of adiposity (Noronha, 2010). The use of CRP has been a standard diagnostic practice for many years in determining the status of known inflammatory disorders (WHO, 2014). This observation could likely be due to increase inflammatory processes which increase as pregnancy progresses. However, in pregnant women, CRP concentrations tend to be higher late in pregnancy (Young et al., 1991).

The level of hsCRP observed in this study was higher than that recorded among pregnant Caucasian women (Gajida et al., 2010). Maternal concentrations of CRP have been studied as an aid to diagnosing subclinical infection in pregnant women who experience preterm labor and premature rupture of membrane. Elevated levels of CRP measured during gestation have been linked to adverse pregnancy outcomes such as preeclampsia and intrauterine growth restriction (Tjoa et al., 2003). Production of CRP is stimulated by the release of proinflammatory cytokines including interleukin-1, interleukin-6, and tumor necrosis factor-alpha (Worwood, 2007).

The mean BMI for anaemic pregnant women was higher $(p=0.017)$ than in non-anaemic group. This may be attributed to reduction or malabsorption of essential nutrient needed for functional erythropoiesis and anthropometry characteristic. The percentage of respondents with BMI below $18.5 \mathrm{~kg} / \mathrm{m} 2$ and $30 \mathrm{~kg} / \mathrm{m} 2$ or above was higher $(p<0.05)$ among anaemic group while the percentage of respondents with BMl $18.5 \mathrm{~kg} / \mathrm{m} 2$ to $24.9 \mathrm{~kg} / \mathrm{m} 2$ and $25 \mathrm{~kg} / \mathrm{m} 2$ to $29.9 \mathrm{~kg} / \mathrm{m} 2$ was higher $(p<0.05)$ among non-anaemic group. However, normal and healthy BMI was lower among anaemic pregnant women $(p<0.05)$. The percentage of anaemic pregnant with low BMI (below $18.5 \mathrm{~kg} / \mathrm{m} 2)$ was higher $(p<0.05)$ $(66.7 \%)$ while overweight was lower $(29.4 \%)$ than nonanaemic group. Weight loss due to nausea and vomiting may likely be associated with early pregnancy thus reflecting in low BMI (Pearson et al., 2003).

The prevalence of obesity in this study was $10 \%$ while that of underweight, normal and overweight was $3 \%$, $72.8 \%$ and $14.2 \%$. However, the prevalence of obesity among respondents in the three study centers were $35 \%$ (42), 43.3\% (52), $21.7 \%(26)$ in Abeokuta, ljebu-Ode and Sagamu respectively. The prevalence of obesity was slightly lower than previous study conducted in SouthEast Nigeria (Chigbu and Aja, 2011) and Austaralia (Callaway, 2006). The prevalence of obesity in this study is similar to the $9.1 \%$ reported from Tanzania (Colatrella et al., 2006).

Serum levels of hsCRP were highly associated with BMl among obese and overweight pregnant subjects. This association was more pronounced among the nonanaemic group. This was similarly documented in overweight women who may have had chronic 
inflammation and increased risk of preterm delivery. Pearson et al. (2003) documented that high BMI is associated with elevated CRP concentration among pregnant women.

The BMI among pregnant women in different trimester shows that BMI increase as pregnancy progresses and may be related to the size of the growing foetus. It may also be an indirect evaluation of nutritional status of both mother and foetus. If the nutritional requirements during pregnancy are not met, the consequences can be serious for mother and their infants. The study revealed that pregnant women in the 3rd trimester have higher BMI. However, the values were higher than those recorded in Kano Northern Nigeria (Kabir et al., 2012).

Obese individuals are often in a chronic proinflammatory state that sharply increases their risk of all degenerative diseases. Elevated CRP levels during pregnancy, as a marker of low-grade inflammation, have also been suggested to be associated with increased risks of foetal growth restriction and neonatal complications, such as preterm birth, low birthweight, and small size for gestational age (SGA) (Poole et al., 2013;Genc et al., 2010;Tjoa et al., 2003). Obesity may be an emerging risk factor for Iron deficiency using BMI index (Aigner et al., 2014). In conclusion, hs-CRP levels were significantly higher in anaemic pregnant women than non-anaemic pregnant women, the elevation of hsCRP levels were associated with severity of anaemia. Adequate ante-natal management of pregnant women cannot be overemphasized to avoid the complications associated with anaemia and inflammation in developing countries.

\section{ACKNOWLEDGEMENTS}

We appreciate the staff of laboratories and ante-natal clinics of OlabisiOnabanjo Teaching Hospital Shagamu, General Hospital, ljebu Ode and General Hospital, Abeokuta, Ogun State for their immeasurable contributions towards the completion of the study.

\section{REFERENCES}

AbouZahr C, Royston E (1991). Maternal Mortality: A Global Fact book. Geneva: World Health Organization.p 5-15.

Aigner E, Feldman A, Datz C (2014). Obesity as an Emerging Risk Factor for Iron Deficiency. Nutrients; 6(9):3587-3600.

Allen LH (2000). Anaemia and Iron deficiency: Effects on pregnancy outcome. Am J ClinNutr, 71(5):1280S-1284S

Brabin BJ, Hakimi M, Pelletier D (2001). Aanalysis of anaemia and pregnancy related maternal mortality. J. Nutr., 131(25-2): 60456155.

Callaway LK, Prins JB, Chang AM, McIntyre HD (2006). The prevalence and impact of overweight and obesity in an Australian obstetric population. Med J Aust.; 184(2):56-59.

Center for Disease Control and Prevention (2007). Morbidity and Mortality Weekly Report.55:1377-1380.

Chigbu CO, Aja LO (2011). Obesity in Pregnancy in Southeast Nigeria. Ann Med Health Sci Res 1(2):135-140.
Choi CW, Cho WR, Park KH, Choi IK, Seo JH, Kim JS (2005). The cutoff value of serum ferritin for the diagnosis of iron deficiency in community residing older persons.Ann Hematol. 84:172]178.

Colatrella A, Braucci S, Festa C, Bianchi P, Fallucca F, Mattei L (2009). Hypertensive Disorders in Normal/Over-weight and Obese Type 2 Diabetic Pregnant Women. ExpClinEndocrinol Diabetes. 17 (8):373377.

Cook JD, Flowers CH, Skikne BS (2003). The quantitative assessment of body iron. Blood 101:3359-64.

Deodhar SD (1989). C-reactive protein: the best laboratory indicator available for monitoring disease activity. Cleve Clin J Med. 56(2):126-30

Du Clos TW (2003). C-reactive protein as a regulator of autoimmunity and inflammation. Arthritis Rheum. 48(6):1475-1477.

Gajida AU, lliyasu Z, Zoakah AI (2010). Malaria among antenatal clients attending primary health care facilities in Kano state, Nigeria. Ann AfrMed;9:188-93.

Genc H, Uzun H, Benian A, Simsek G, Gelisgen R, Madazli R (2011). Evaluation of oxidative stress markers in first trimester for assessment of preeclampsia risk. Arch GynecolObstet ;doi: 10.1007/s00404-011-1865-2.

Haverkate F, Thompson SG, Pyke SD (1997). Production of C-reactive protein and risk of coronary events in stable and unstable angina. European Concerted Action on Thrombosis and Disabilities Angina Pectoris Study Group.Lancet.349(9050):462-466

Hinderaker SG, Olsen BE, Lie RT, Bergsjø PB, Gasheka P, Bondevik GT, Ulvik R and G Kva G (2002). Anaemia in pregnancy in rural Tanzania: associations with micronutrients status and infections. Eur J ClinNutr. 56, 192-199.

Kabiru T, Hafiz A, Atiku MK (2012). Nutritional status in pregnant women attending Kiru general hospital in Kano state, Nigeria.Bayero J Pure Applied Sci, 5(2): 119 - 121.

Knapen MFCM, Zusterzeel PLM, Peters WHM, Steegers EAP (1999). Glutathione and glutathione related enzymes in reproduction. Eur $\mathrm{J}$ ObstetGynecolReprodBiol .82:171-184.

Mandal KK, Das A, Devi HL, Omita N, Singh NN, Singh WG (2016). Serum high sensitive C-reactive protein as predictor of preeclampsia. IOSR J Dental Med Sci 15(2):26-31.

Murphy JF, O'Riordan J, Newcombe RG, Coles EC \& Pearson JF (1986). Relation of haemoglobin levels in first and second trimesters to outcome of pregnancy. Lancet, 1: 992-995.

Noronha JA, Bhaduri A, VinodBhat H, Kamath A (2010) Maternal risk factors and anaemia in pregnancy: a prospective retrospective cohort study. J ObstetGynaecol. 30(2):132-6.

Nwizu EN, lliyasu Z, Ibrahim SA, Galadanci HS (2011). Socio Demographiand maternal factors in Anaemia in pregnancy at booking in Kano, Northern Nigeria.Afr.J.Reprod.Health, 15(4):33-41.

Ogbodo SO, Okaka ANC, Nwagha UI, Ejezie FE (2014). Free Radicals and Antioxidants Status in Pregnancy: Need for Pre- and Early Pregnancy Assessment, Am J Med MedSci, 4(6): 230-235.

Ogbodo SO, Okaka ANC, Nwagba UI (2013). Anti-infective antioxidant minerals levels in uncomplicated pregnancy in some rural communities of south East Nigeria. J Med Nutr Nutraceut.2:52-57.

Pearson TA Mensah GA Alexander RW (2003). Markers of inflammation and cardiovascular disease: application to clinical and public health practice: a statement for healthcare professionals from the Centers for Disease Control and Prevention and the American Heart Association. Circulation.107:499-511

Pitiphat W, Gillman MW, Joshipura KJ, Williams PL, Douglas CW, RichEdwards J (2007).Plasma C-Reactive protein in early pregnancy and preterm delivery. Am J Epidemiol 162(11):1108-1113.

Poole EM, Lee IM, Ridker PM, Buring JE, Hankinson SE, Tworoger SS (2013).A prospective study of circulating C-reactive protein, interleukin-6, and tumor necrosis factor a receptor 2 levels and risk of ovarian cancer.Am J Epidemiol. 178(8):1256-64.

Redman CW, Sacks GP, Sargent IL (1999). Preeclampsia: an excessive maternal inflammatory response to pregnancy. Am J Obstet Gynecol.180:499-506.

Scholl TO, Chen X, Goldberg GS, Khusial PR, Stein TP (2011). Maternal diet, c-reactive protein and the outcome of pregnancy. $J$ Am CollNutr 3(4):233-240.

Shetkar NR, Pyati AK (2017). Study of serum high sensitive C-reactive 
008 J. Med. Med. Sci.

protein and ferritin in preterm labor. Int $\mathrm{J}$ ClinBiochem Res 4(3):213215.

Tjoa ML, van Vugt JM, Go AT, Blankenstein MA, Oudejans CB, Van Wijk IJ (2003). Elevated C-reactive protein levels during first trimester of pregnancy are indicative of preeclampsia and intrauterine growth restriction. J Reprodlmmunol. 59(1): 29-37.

Van den Broek NR, Letsky EA, White SA, Shenkin A (1998). Iron status in pregnant women: Which measurements are valid? BritJ Haematol. 103(3):817-824.

Vermeire S, Van, AG, Rutgeerts P (2004). C-reactive protein as a marker for inflammatory bowel disease.Inflammat Bowel Dis, 10(5):661-665.

WHO (2014). C-Reactive protein concentrations as a marker of inflammation or infection for interpreting biomarkers of micronutrients WHO/NMH/NHD/EPG/14.7;1-4.

WHO international standard.Human C-reactive protein 1st international standard. NIBSC code: 85/506. Instructions for use (version 3.0, dated 19/03/2008). Hertfordshire: National Institute for Biological Standards and Control; 2008 (http://www.nibsc.org/documents/ifu/ 85- 506 .pdf, accessed 10 June 2016).

WHO (1989). Preventing and controlling Iron deficiency anaemia through primary health care: a guide for health administrators and programme managers. Geneva, World Health Organization:p.1-6.
WHO (1995). Physical status: The use and interpretation of anthropometry. Report of a WHO expert committee.Technical report series No. 854. WHO

WHO/CDC (2008). Worldwide prevalence of anaemia 1993-2005: WHO global database on anaemia. De Benoist, B., McLean, E., Egli, I., Cogswell, M. eds. World Health Organization, Geneva. Available at http://whqlibdoc.who.int/publications/2008/9789241 596657

Worwood M (2007). Indicators of the iron status of populations: ferritin. In: WHO, CDC. Assessing the iron status of populations: report of a joint World Health Organization/ C for Disease Control and Prevention technical consultation on the assessment of iron status at the population level, 2nd ed. Geneva, World Health Organization: 35-74.

Young B Gleeson M Cripps AW (1991). C-reactive protein: a critical review. Pathology,23:118-24)

Zimmerman MB, Hurrell RF (2007). Nutritional iron deficiency. Lancet; $370: 511-520$ 